\title{
THE LAW OF INHERITANCE;
}

OR,

\section{THE PHILOSOPHY OF BREEDING.}

"Still, through her motes and masses draw Electric thrills and ties of law,

Which bind the strength of nature."

- EMERSon.

B Y E. LEW IS STURTEVANT, M. D., WAUSHAKUM FArM, South Framingham, Mass.

[From the 22d Annual Report of the Secretary of the Massachusetts State Board of A griculture.]

\section{BOSTON :}

WRIGHT\& POTTER, STATE PRINTERS,

79 Milk Street (CORNer of Federal).

\section{5 .}





\title{
THE LAW OF INHERITANCE;
}

or,

\section{THE PHILOSOPHY OF BREEDING.}

\author{
"Still, through her motes and masses draw \\ Electric thrills and ties of law, \\ Which bind the strength of nature."
}

$$
\text { - Emerson. }
$$

\footnotetext{
Br Ed LEWIS \&TURTEVANT, M. D., Waushakum Farm, South Framngham, Mass.
}

[From the 22d Annual Report of the Secretary of the Massachusetts State Board of Agriculture.]

BOSTON :

WRIGHT\& POTTER, STATE PRINTERS, 79 Milk Street (CORNer of Federal).

1875 . 


$$
\begin{gathered}
S F_{105} \\
.893
\end{gathered}
$$




\title{
THE LAW OF INHERITANCE;
}

\author{
on,

\section{THE PHILOSOPHY OF BREEDING.}

It is now nearly three years since I made my first attempt to write a work on the breeding of domestic animals. I had collected a considerable mass of information, chiefly so-called facts, and it seemed an easy matter to bring these into shape for the illustration of principles which could be enunciated as laws. I soon, however, realized the difficulty of using this material to produce an harmonious result, as the grouping was not only arbitrary, but the laws which they were intended to illustrate were but empirical formulæ, whose mutual connections could not be shown. I therefore determined to seek, through further study, a solution for my difficulties; and I may here say that my realization of the importance of force as fashioning the phenomena of vitality came entirely from a series of inductions. The facts were grouped under laws which seemed to formulate the conditions under which they occurred, and these laws, in turn considered as unities, pointed unmistakably to a superior law, which in its turn influenced their occurrence,- - the law of persistence of force. This brief paper is not presented in order to prove a theory, but as an outgrowth arising from the supposed recognition of a cause.

The cell was taken as the groundwork of my scheme, for microscopic study had familiarized me with these unities of vitalized structure, and belief in a reign of law had led me to 
a firm conviction that the working of natural law was universal; and if completed structure was governed by any power, then the individual parts of that structure must be influenced by the same ruling. Hence the search after truth must be from the simple to the complex, rather than the reverse.

Every change of matter must be produced or caused by some previous condition, for every effect must have its cause. This which accomplishes is called a force, and the change is the measure and exponent of the force used. Force is, therefore, a conception of a real existence, which, although unseen to our eyes, and not cognizable to our senses, can be studied from its effects, for these are seen and recognized, and may be grouped; they can in turn be converted into the unseen, and again be reconverted into the seen, and, through modern science, so measured and accounted for, that it may be said with certainty, forces are indestructible. Forces are also strictly subject to the law of quantity. A given quantity of one force can produce a definite quantity of another. The conversion of a force may change its apparent character, and the phenomena produced by the two forms may be widely different. This is illustrated in heat and motion, electricity and magnetism, animal and vegetable life.

Like causes produce like effects when acting in a similar manner on similar material. We know that forces may be represented by forms, and that difference of form will indicate a difference in the construction of the force.

Force is the agent which produces changes. It has, as a conception, a numerical value and a direction of action. It can, therefore, be increased or diminished, and its direction may be interfered with or antagonized by other force. The concrete force is the equilibrium of all these opposing forces. Any change must be produced by an equivalent change in the force which is represented by the object undergoing change.

This work is but applying the doctrine of persistence of force to vitality, as it has already been applied to physics. The forces governing vitality, chemistry and physics, must needs be but forms of the same force. Nature seems to work always under law, and her phenomena, in successive group- 
ings, continually point to governing laws, and these in turn to others, until we must conceive of one great final law, in infinity, to which all others are subordinate.

\section{INTRODUCTORY.}

In the higher classes of animals our first knowledge of the individual life is of the union of two germs, - the one furnished by the female, the other by the male. The product of this union is a determinate one, and is influenced in a varied degree by multitudinous causes, the more proximate of which are parentage and environment, and the more remote the antecedents of the individual and the race.

The creation of the individual and the fixing of a type for a domestic breed is, under law, largely within the power of man, and the understanding of the action and reaction of law on law, in the production of certain ends of animal structure and function, constitutes the science of breeding.

The science of breeding is not necessarily an exact science. It deals with concrete phenomena, and its predictions must be, in the main, general. By acting in conformity with its predictions, the probabilities of the successful attainment of our ends in the individual is very largely increased; when individual knowledge of the laws of causation is understandingly applied to the problem of breeding certain results from an animal of known antecedents, the probabilities of the position have a near approach to certainties.

The scientific breeder is one who applies the laws governing the art with an understanding of the reasons upon which his expectations are based; while the practical breeder is one who follows rules established by experiment and belief for the government of produce and production. It is as the art of breeding is united with the science that the best results may be expected; and practice is dependent on science for its correctness and the enlargement of its usefulness.

To the believer in causation-a principle which underlies the practise of all science-the animal structure and function is a result produced by, and in conformity to, law; and were the whole history of all the forces which have taken part in the production of individual animals so laid out before a 
mind capable of investigating the process, and which could so estimate their various values as to project them in a mechanical form, a figure could be drawn in which the resultants of the forces could be represented by a line, which would invariably indicate the value of the concrete forces which would be the contribution of the parties to reproduction. This is to say that certainty of result would follow complete and exact knowledge, and the corollary is equally obvious, that when we have uncertainty in practice, it can be explained by the deficiency of our knowledge.

To demand this complete knowledge is to demand a mind which is infinite to our present conceptions; but it is in our power to continuously encroach upon the borders of our ignorance, and, while extending the boundaries of our knowledge, gain increased control over the forces of nature.

The study of physics, or philosophy applied to nature, to me, at least, indicates the possibility of "spontaneous * generation." But as this doctrine, so reasonable in itself, is the subject of so much prejudice, and not as yet satisfactorily demonstrated, we may at present claim that life is always derived from preëxisting life. The terms which we apply to this derivative process are reproduction and generation. The word reproduction is general in its meaning, and includes the history of the changes which take place in the organs and functions of the individual, by means of which new matter is formed, as well as the production, growth and development of the new germs which make their appearance through generation. The word generation, strictly speaking, has reference only to the changes immediately following the act of begetting, but usually includes somewhat of the past history of the separate cells which take part in this process, as well as some history of the development of the new life thus formed. The generative process appears to consist essentially in the union of the contents of two cells, or the differentiated product of one cell, by which the germ of what may

* Spontaneous: I use the word in the sense of produced without any special cause or method being assigned, as of the appcarances of life without any evidence of its being produced from an existing vitality, - that is, the convertibility of forces. To use the word as if it involved the production of life without cause, or not in accordance with law, would involve an absurdity of thought. 
become an independent life is the result. Development is the sequel to generation.

The reproductive process in itself consists in the formation of certain cells from preceding cells through well-defined procedure. It may be by subdivision, by gemmation, or through the intervening act of generation. When, by subdivision or by gemmation, each act of development appears to diminish the germinal capacity; when, by generation, the germinal capacity appears to be renewed. By subdivision is meant the method of multiplication of cells, which, for a time, may retain their juxtaposition; by gemmation, the formation of cells which are to be cast forth, the commencement of a separate existence. The reproductive process includes the repair of injuries and the increase and renewal of parts. Growth may be the sequel to reproduction.

Life may be said to commence with the cell, for it is only at this stage that we ordinarily recognize individuality. In the higher animal structures, as in the mammalia, we have the whole structure either built of or derived from cells, presenting a most varied and complex appearance as viewed in their completed state, but which, when studied with reference to their history and development, are seen to be all derived from this same formative element. Each cell is or has been at some time, within certain limits, an individual and independent whole, in which the vital processes are or have been repeated; as in one, so in all. Although presenting this apparent individuality, yet, in the animal structure, these separate units are all combined, each with all, to form the harmonious whole,-the animal life.

The study of the cell is the foundation from which the science of breeding is to be built up, for natural law is universal and simple and unvarying, acting on all alike, but its actions disguised by environment. That the law may be seen in its primal force, it is necessary that its workings should be sought for amid the simplest conditions and amongst the least complexity of structure.

THE CELL.

The cell proper, or the ideal cell, is a homogeneous and extremely simple structure, which may be defined as merely 
substance within an enveloping membrane. Within a cell we usually expect to find a nucleus, or, possibly, within the nucleus another cell, which we call a nucleolus. These inner cells are almost invariably of a round or oval form, offer greater resistance to the action of chemical agents than do the external parts, and are those parts which are the most constantly found unchanged. The nucleus seems less connected with the function and specific office of the cell, according to Virchow, than with its maintenance and multiplication as a living part.

For the existence of the cellular element, such as we are to consider, two things are requisite,- the membrane and the nucleus. The contents change according to position and function. With these two forms,-the membrane and the nucleus, -we are enabled to examine critically the basis of some of the phenomena attending life.

In the embryonic state we can readily detect the time when the whole structure is composed of cells, and as we pass onward towards birth, we see these cells changing their form and function, becoming differentiated as it were, in an increasing ratio with the age. The cells multiply, change their form and their function, which necessarily involves their contents, until in the grown individual it is difficult to trace the connection between these elements in the various parts. The cells change, but while the activity of the cell remains, the nucleus can usually be detected. The muscle-cells become elongated and become filled with contractile matter, and capable of transmitting force; the nucleus remains attached somewhere to this cell and is unchanged. So with the nerve-cells; the contents differ from the muscle-cells, and it is but the nucleus which remains to indicate the kinship. We also find changes going on in the shapes of cells by outgrowths, by division, by absorption, and even by secretion and growth. These cells containing nuclei are, in fact, individual units of a living organism, and themselves containing life and undergoing vital processes, go to make up the concrete life we recognize in the formed animal.

As the processes which these vital unities pass through are all allied, we can consider some of the laws of reproduction, as derived from the study of the simple or ideal cell, leaving our 
considerations concerning generation until we shall trace the union of the sperm and germ cells, and are prepared to study the development resulting therefrom. We can the better proceed in this course, if it is continually borne in mind that the cell is in a certain sense an independent being, and rules arbitrarily over certain surrounding limits. In some tissues, where there are intercellulitr substances, each cell rules, as pathological investigation shows, over its own defined territory. In other tissues in which the cells are contiguous, each cell can run its own course without the fitte of the cell lying next to it being necessarily linked with its own. In a third tissue we find the cell-elements more intimately connected with each other: as, for instance, a stellate-cell may anastomose with a similar one, and in this way a reticular arrangement may be produced similar to that seen in capillary-ressels and other analogous structures. Yet even in this chain-mork of cells, individual cells, in consequence of certain internal or external influences, undergo certain changes confined to their own limits, and not necessarily participated in by cells adjoining. (Virchow.)

Each cell in its development reproduces itself.-The manner of the development need not concern us in this place. Although primurily the ideal cells are in form alike, yet through the differentiation arising from complexity of structure, we see existing cells of apparently willely different origin. We have, for instance, the hepatic-cell, columnar epithelium, cells of comnective tissue, muscle-cells, nervecells, etc., etc. In the animal organism there is a continual using up of tissues. The food passing into the body supplies the material for supplying the wastes, and cells absorbing their share at the necessary time reproduce or repair their form or their substance. That form of epidermic cells found in the nail produces nail-cells; epithelial-cells, epithelium, etc. When the hand is cut the muscles unite hy their orn appropriate tissue; the skin heals in a like manner. When the nail is injured the remaining cells multiply themselves, as in growth, until the injury is more or less repaired. Remove the nail-cells, and the surrounding cells are unable to derclop themselves into nail.

Each cell in its development is affected by its environment.-If 
the development takes place under circumstances that resistance is less in one direction, they may shoot out in this one direction, and become elongated. This is well shown by columnar or cylindrical epithelium, or hy transitional epithelium, as named by Henle, when the cells anequire points, jags and projections in the direction of least resistance, and in the epithelium of the skin. Making a section of the slin, we invariably find flat and closely-packed cells in the epidermis, with the cells on the innermost layer less llattened, and with nuclei. The further we advance inward the smaller do the cells become, the last of them standing in the form of little cylinders on the surfice of the papillar; the epidermic cells being an advanced stage of growth, in proces:3 towards desquamation, the inner layers the formative cells, as shown by the nuclei. Pathologically, this law is illustrated by cancer-cells, which, like the eorpuscles of pus, take their rise from the preexisting cells and nuclei of the texture or organ in which the new growth originates.

The influence of environment is conclusively illustrated by the study of the development of some fungi, whose spores are vegetable cells analogous to the animal cell.

When the spores of pencillimm crustacem are scattered on at substance having the same chemical composition as that from which it was taken, a new crop of pencillium crustaceum is the result:

Now, sow these spores on distilled mater, and they swell up and linally burst, with the expulsion of a great number of minute bodies called zoöspores, which finally develop into a plant which has been named leptothrix.

If these same spores are put under the surfice of a liquid rich in nitrogen, the zoöspores expelled develop into a micrococeus; if the liquirl is poor in nitrogen, a cypto-coceus is developed.

If these spores are sown in milk, which is a fluid rich in nitrogen, we have a micro-coccus appearing, but as the milk sours by lactic acid being formed, the zoöspores instead of passing into a micro-coceus form, change to an arthro-coceus. If, again, a pencillimm-spore germinates on milk just below the surfice, we have another form called oidimm lactis.

If, again, a pencillium-spore is sown in fermented wine or 


\section{The Philosophy of Breeding.}

beer, wherein all the sugar hats been converted into alcohol and carbonic acid, we have still another form, mycoderma acetis.

Each cell appear's to reproduce itself as it is at the time, and we thus have development at corresponding periods. The fitness of each portion of the body for its present requirements is in this manner secured; and on this principle of a like inheritance can be explained the marvellous fact that each portion of the body is adapted to its coöperation with other portions of the body. Were distant progenitor's as powerful in their influence on the progreny as others more near, the animal, instead of its present harmony of construction and function, would be an inharmonious mass of independent vitalities. We find, in accordance with this law, that in the embryo, parts appear which are fitted for offices and relations which are future. If, as appears to be the case, each cell reproduces itself, and is also in turn aflected by environment, it would be in effect a denial of the persistence of force, as Herbert Spencer observes, to expect that $\mathrm{A}$ can become $\mathrm{A}^{1}$, and still produce the same progeny as if it were still $A$. We may have, then, in a cell constant change, with a continual reproduction of the original, and thus a definite point may be fixed, through inheritance from the past, for each cell to acquire those functions for which it is suited. Adaptation, therefore, comes through the influence of forces acting in the past, and its presence is not only determinate, but is explained by philosophy.

As each cell reproduces itself as it is, including the variations brought about by inheritance and otherwise, it seems reasonable to suppose that as all the body stands in relation of euvironment to each cell, and produces changes which, in turn, are transmitted,-_cause and effect, persistence of force, irrevocable law, - so the spermatic cell has the power of transmitting all the inherited variations brought about by the totality of the individual, including his past. Inherited variation or persistence of force seems a more philosophical hypothesis, nay, I will say theory, than pangenesis.

In those cases of repair after injury, as is noticed by Paget, in an adult animal, when a part is reproduced after injury, it is made in conformity, not with that condition which was 
proper to it when it was first formed, or in its infuntile life, but with that which is proper according to the time of life in which it is reproduced. In the reproduction of the foot or the tail of the lizard, they grow, as it were, at one into the full dimensions proper to the part, according to the age of the individual.

Each cell appears to be limited in its pomers of inclefinite expansion, and thus some connection is constantly preserved between the early embryotic cell and the future progeny. That is, as Paget well expresses it, the calpacity of assuming the specific organic form camnot be communicated to an indefinite quantity of matter, for undoubtedly there is a consumption of power in each organization of new matter, and in the growth and maintenance of those parts alleady formed. We lave thus in the primal force a natural limitation. This reproductive force appears stronger in the young than in the old, and it would, therefore, seem as if the formative power is more diminished by growth than by mere maintenance. But again, as our author observes, the capacity for the repair or reproduction of injured parts is much more diminished by development tham hy growth or maintenance of the body; that is, much nore hy those transformations of parts by which they become fitted for higher oftices, than by the multiplicittion or maintenance of those that are already perfect in their kind and function. In other words, to improve a part requires more and more perfect formative power than to increase it does.

Changes may originate in a cell from cessation of force.If the cessation be final, we have destruction of form, or, as we say, dead matter. If partial, an incompleteness, or at check to the development of the new cell may result. The forces which originate a cell, and which are contained within the new cell, appear to principally aflect the development, while growth is largely firom forces derived through mutrition. This law of cessation of force oftentimes olssemes the presentation of other laws, especially the laws of similarity.

The cell is an entity, containing within itself its peculiar fores, deriver through inheritance and from its environment. The forces must be derived from somewhere, for energy can- 
not be created.* Life is potential,-that is, endowed with energy. Its every manifestation proceeds from the utilization of force. Inheritance is but an expression of a local fuct, included in the phrase persistence or correlation, conservation or convertibility of force. It can, therefore, be studied in its relations to law.

Like produces like in the cell; for we have in the new cell but another expression of the parent cell, brought about from and through the transference of force. As every force acting on a cell must produce some effect (for cause and effect are correlative, of necessity), we needs have changes produced through environment, and the cell in which these changes are produced camot be the same cell as it was previous to such changes, and can, in the line of transference of force, but reproduce itself as it is. There must needs be, then, in the cell a series of reproductions, in order to gain development. As another sequitur, we have limits to the power for reproduction, for work can only be performed by the use of enorgy, and each change in a cell is an expression of work performed or energy used; and when the changes demanded by environment are too great fur the remaining forces of the cell, and new forces camnot be assimilated from elsewhere, there must be a cessation of reproduction, and in time a destruction of form.

\section{THE SPERM.}

In considering the cell, we remarked upon the functions of the nucleus as teuding rather to the maintenance and multiplication of the cell, than to its specific office. In the sperm we shall have occasion to again refer to this important province of the nucleus.

The semen-or the contribution of the male animal towards the greneration of offspring-consists essentially of the spermatozon. Besides this, the product of the testicle, the cjected fluid contains the secretions of other glinds, which probably serve the purposes of dilution for the fluid in which the spermatozoa move. Certain it is, from the beantiful experiments of Mrr. Newport, that impregnation does not take place until the spermatozoün actually comes in contact with the ovum, and penetrates within its substance.

\footnotetext{
* That is, formed from nothing, - an unthinkable proposition.
} 
The spermatozoön differ's in aspect in various animals. In man it is a perfectly clear, hyaloid, filamentous body, in which a dilated portion called the head may be observed, from which is prolonged a tail or filament, which generally tapers to an extremity hardly visible from its tenuity. The head, or Targer extremity, is flattened from side to side, and of a conical form, the pointed extremity being anterior. The spermatic filament of the bull is somewhat similar, but the blunt portion of the oval is anterior, and there is a tendency to exhibit a darker anterior and a clearer posterior portion. In the rat and mouse the head or body of the filament is unsymmetrical and eurved. In the common cock the heads are oblong and considerably elongated; in the common sparrow, wary. In the common perch the spermatozoa exhibit a rounded head; in the river crawtish the filaments radiate fiom the circular head, and are numerous.

When the spermatozoa have escaped from the male passages their aetive movements commence, and, by the continuous vibratory or other movement of the filamentous tail, they are propelled forward. The tail alone has the power of movement, and it wisps about with an energy sufticient to move many times the weight of the spermatozoün. In the interior of the female organs of generation these movements are continued for a longer period than in any other situation. In the queen bee the capacity for movement is retained for sereral months after they have been discharged by the drone bee; and in the mammalia the movement may continue for several days after copulation. Leuwenhock points out that the spermatozoa of the dog will live or retain their movements for more than seven days preserved in a glass tube; and Dr. Perey, of New York, reports a cuse where living spermatozon issued from the os uteri of a female eight and a half days after the last sexual connection. In a bat that had been isolated for thirty-six hours, both the vagina and uterus were filled with spermatozoa in lively movement.

Even this full development does not, in all cases, seem necessally for the fulfilment of the function of the spermatic filanent. In certain animals, such as the decapod crustacea and others, the spermatic elements are cast forth by the male, and are transferred to the orgaus of the female while they are 
simple cells, which, during their subsequent life, form spermatozoa within the passages of the female, as they would have done within the organs in which the spermatic cells were first formed, the requisite conditions being duly supplied.

We will now touch upon the history of the development of the spermatozor, and will thus trace their kinship with the cell. In the earlier stages of physiological science they were regarded in the light of animalculat. At the present time they are considered as epithelial cells, or, as Dr. O. W. Holmes expresses it, are related to ciliated epithelium.

They are, as has been before stated, the product of the testes. The testicles are a couple of true glands, containing the secreting elements in the form of complexly convoluted tubules, - the spermatic tubes, or tubuli semeniferie. These consist of a fibrous coat, internal to which is a basement membrane surrounded by epithelium. The character of this epithelium and the contents of these tubes vary with the age. In boys and young animals the slender tubuli contain nothing but minute, clear cells, the most external of which may be regarded as epithelial cells. The spermatozon are not found in these tubes until puberty in man, and among some animals are only developed at certain periods. The epithelium lining the tubes is most distinct when spermatozoa are not being found, but when the function of the gland is being actively performed the tubes are seen to be entirely occupied by cells, filled with nuclei, in which the spermatozoa are ultimately developed.

The method of development is thus described by Todd and Bowman: "The cells become detached from the basement membrane, increase in size, and assume a more spherical form, the contents at this time being entirely granules; at length, however, several clearer points or nuclei are seen in the interior of the cell, which is now passing down the tubule towards the vas deferens, while it is succeeded hehind by the formation of new cells. The nuclei in the interior enlarge, and are often seen to contain nucleoli. The parent cell having much increased in size from the development of its nuclei into cells, appears to undergo no further change; but in each of the contained cells, which vary much in number, one spermatozoön is developed on the inner wall, in the form of a spiral 
tilament, as wis first described by Kolliker. The spermatozoin escapes into the interior of the mother cell hy the rupture of its development eell. Others are in like mamer set free, and they arrange themselves in a parcel, which may ultimately consist of a rast number of separate spermatozoa, with all the heads arranged in one clirection, and the tails in the opposite one."

I'rofessor Kolliker has arrived at the conclusion that the spermatozon are not developed in the nuclei of the eells, but from them. The nucleus hecomes of an oval form, and one extremity is elongated to form the tail.

It is thus seeu that the spermatozoön is a living mit which originates from within the cell, and appears to be developed from the nucleus, which, als we have before stated, scems to be the one element of all cells which concerns itself with their protuction: and as is shown by those calses of cells at emission being dereloped into the spermatic filament in the female passages, there is a developmental power inherent in the cell after it has become detached from the basement-membrane, or, in other words, has changed its appearance but little from the ordinary epithelium. The production of these cells seems to be somehow analogically allied with the process of gemmation, as in the ideal sperm-cell and the ideal bud. We have, at first, a separation from the parent, and, secondly, may hare the erolving of apparatus to be used in reproduction. At this point the resemblance seems to he lost, ats in the spermatic element there is absolutely required, so far as we know, that there sball he a meeting and mion with another cell to complete the new life, while in the gemmation process, the spore itself, as in the female, may develop itself into a structure containing organs from which the new generation originates.

This spermatic-cell is allied with the other cells of the body, as with the whole hody it has been formed through the sncessire derelopment of cells,_-simple until after fecundation. It apparently is primarily an epithelial cell, and it is only as the boly within which it is found attains age, or, as is probilhe, it is only after cell has reproduced cell for many generations, transunitting its own likeness eatch time with the aceumulated and acemulating rariations, that the spermatic 
filament is formed; that is, heing a highly-endowed structure, it can he formed only through successive reinforcements of force, or successive developments; that is, it must pass through the stated eourse of heredity with variation. Its afterfunctions, or, ats we mily express it, the inherent power locked up in these minute filaments, in man scalcely one-eight hundredths of an inch long, indicates high endowments, just as the power extracted from a lump of coal is the measure of the power which was made latent in the stone form in its production. This is also apparent in the close connection lnown to exist between the nervous system and the organs of generation and the physical lassitude following their abuse. This close connection between the nervous and generative systems explains some of the problems attending the study of inheritance.

Each cell partakes, it is probable, through inheritance with variation, of the ehanges which have taken place, and which are taking place, both mentally and physieally, in the body. It is a concretion of possibilities derived through a long course of vital changes, and which is enabled, under fivorable circumstances, to transmit its aceumulated powers, through union with another cell, to a remote posterity. The hypothesis of pangenesis demands the presence of granules or gemmules which are freely circulating through the system, and which are supposed to be transmitted from the parent to the offepring, and which can lie dormant or become developed in the generations that suceed. To me, this is unthinkable, and I prefer to suggest that the law of persistence of force requires that no change can take place in a cell without changing the possibilities of that cell in its multiplication and future development; that each cell is the sum of all the forces which have acted on it in the past and are acting in the present; that the intimate connection of the generative cells with the whole body, arising through their high endowment, stores up) in them a greater store of possibilities, hrought about by their extreme complexity of enviroument.

These possibilities may be looked upon as forees which are modified by every antagonistic force, and, strengthened hy every force acting in their own direction, only require suitabble conditions to become developed or affect derelopment,- 
that is, to add forces so as to be changed into other forees. In a word, inheritance is but the transmissal of forees, and inheritance ean be general in respect to the whole body, and local in respect to the tissues and parts of the body.

In the history of the development and in the formation of the spermatozoön we reeognize a segregation and localization, - that is, the putting into form of forces; and when this spermatozoön unites with another cell,--the ovum, under certain conditions, - a union of forces takes place, and, the phenomenon of individual life being thus superimposed, these forees are able to accumulate and store up the forees necessary in turn for development, growth and future transmissal. The whole form and character of the individual is the equilibrim of the forces which were united to give him birth, and those additional forees added on or influeneing during life. If we suppose development and growth taking place, or any of the phenomena attending vitality, without the corresponding expenditure of power, we are involved in an absurdity; for appropriation of and transmissal of force, not its creation, is consistent with the reign of law, such as modern science recognizes as existing.

In this place it may be well to define our understanding of force. It is a power which produces change, or acts to chauge any relations whatsoever between matter, -as the foree of gravity, cohesive foree, centrifugal force, vital force. Modern scicnce has determined that forces, like matter, are indestructible, and that many of them are mutually convertible, and that these mutations are rigidly subject to the laws of quantity. Every manifestation of force must needs come from a preexisting equivalent force, and must give rise to a subsequent and equal amount of some other force. We have laws governing force as we have laws governing matter. Every change involves expenditure of force.

As a summary, we may look upon the spermatozoün as a cell, the representative of the organism through which it has been developed; as one of the individual unities which are freighted with fore beyond its own needs, and but recpuires the suited conditions of union with the proper germs under suitable circumstances, to develop that. foree. Just as, for illustration, we may consider coal or water as the represent- 
ative of the forces used in their formation. Through the destruction of their power, their forces can be liberated to again pass into other powers of energy.

\section{THE GERM.}

That portion of the female organism which most nearly conforms to the spermatozoön of the male, is the ovum, or egg, or, more aceurately spealking, the most essential part of the orum, the germinal spot. The germinal spot appears to correspond to the nuclens of the cell in many respects. The germinal resicle, in which the germinal spot is contained, appears a cell surrounded by a mass of nutrient matter lsnown as the yolk, and the whole surrounded by a vitelline membrane or yolk-sac.

The orum takes its origin from within the stroma, or the cavity of the ovaries, which answer analogically to the secreting process of the testicle. In many of the lower animals the testes and ovarics bear a close resemblance to each other, and the same holds good in the early or embryotic conclition of the generative apparatus of man. In some of the lower grades of animals, as generally in the articulates and mollusks, the ovaries have a glandular character, but in the rertibrates the ova are evolved in the midst of a solid fibrous tissue or stroma.

The likeness between the spermatozoa and the ova is again inclicated by the fict that they both appear to be the product of cell-action, with development having taken place after the dehiscence of the cell from its companion cells. We thus have in the sperm the mother-cell containing the nuclei which are formed into ciliated cells, and which are to develop a vitality sufficient to support the motion necessary to them for the fulfilment of their uses. In the ovum we recognize an advanced development, in which the cell containing its nucleus is the essence; the nucleus in both being the essentiul part for the exercise of the complete function of either, - the production of the individual life.

The ova in women originate in ovisaes or follieles, usually termed Graftian resicles, which are imbedted in the more peripheral portions of the stroma. Eatch follicle in its fully formed condition consists of a membrane and contents. First, 
a highly vascular layer which is united with the stroma of the ovily hy at rather loose connective tissue. This membrane is composed of undeveloped, nucleated, formative tissue, intermixed with numerous, mostly fusiform, formative cells. Second, an epithelium lines the entire follicle, and on the side looking towards the surfice of the ovary, where the ovum is situated, presents a wart-like thickening projecting towards the interior and enveloping the ovum. In this germinal eminence, as it is called, close upon the fibrous membrane of the follicle, and, therefore, in the most prominent part of it, is placed the egg (ovulum) imbedded in the cells of which the eminence is composed.

In the articulated and molluscous animals generally the orum is produced from ovaries, which have a glandular character,those of the former retaining a vesicular type; of the latter, often prolonged into convoluted tubes.

In the ovaries of the advanced foxtus and new-born child, Giratfian follicles are abundant, and the ovum can he seen within them. According to Dr. Ritchie, there is a continual rupture of ovisacs and discharge of ova taking place even during childhood; and I have myself verified this observation in the ovary of a calf but a few days old. It is only as the period of puberty is reached that the ova are perfectly developed and capable of being impregnated.

The number of ovat which may be produced by a single animal is inmense. In fishes the number is simply inconceivalble. The number spawned by a single cod is stated at from one to nine millions. In the herring as many as sixtyeight thousand six hundred and six ova have been counted from one fish. Among animals of the higher order's we also have an ample provision. Dr. Barry ealculates that the ovary of the cow, at the period of puberty, contains as many as two hundred millions ovisacs to a cubic inch of the stroma." In the human female the ovary may contain from thirty to one hundred follicles.

In the absence of proof, it seems philosophical to suggest, that, judging from analogy, the ovum is directly the resultant of cell-action; that cells in the stroma, through a process of reproduction, finally arrive at a stage where a certain incle-

* Todd and Bowman's Physical Anatomy, p. 818. 
pendence of action can be sustained, and development proceeds, aided by the actions going on simultaneously in the surrounding cells, producing changes on them, and having changes produced in them in turn on themselves. The existence of and discharge of ova during childhood, and the incompleteness of the orianization of such ova, by which impreguation is rendered impossible; the existence of the nuclei, which suffer less change, or resist changes longer than the cell; the formative power which the cells of the ovary appear to possess even after the extension of the ova, as witnessed in the corpus lecteum; the numbers of ova heyond all seeming needs; the appearance of the germinal vesicle first in the order of development, and the analogy between the sperm and the germ in their development, are all suggestive of this view.

In the preparations for fecundation the mother-cell of the testes possesses nuclei which develop into spermatozon and are scattered as animated particles within the secretions of the seminal tubes. In the ovum, as a preparation for fecundation, it seems probable from the observations of many skilled observers, that the germinal vesicle is dissolved (like the mother-cell), and the diffusion of its contents (which originate or are formed from the germinal spot or nucleus) through the yolk, which may be considered in some sense a secretion.

Certain it is that the ovum, like the spermatozoön, represents vitality. A period in its development arrives when it becomes capable, under fit conditions, of establishing an individual and independent life. This condition of vitality may remain for a considerable, though uncertain, period of itself; the ovum has reached the highest development that it is ordinarily capalsle of, and it requires for its future development a set of conditions external to itself, the union of the fecundating germ and fit surroundings.

This ovum is, however, filled with possibilities. It contains, as does the sperm, elements which may go to make up an individual and independent life, and is one of the connecting links which unite all the vital forees of the past with future generations. It is a vehicle for the transmissil of the forees which have had part in its own evolution.

Each cell or completed ovum contans its own forees, which 
camnot be alike in each, such is the complexity of environment, but which ean approximate in likeness according as the conlitions of their evolution have been more similar. We camnot expect that in the continual development of ova into new beings-although the conditions of the environment of the development brought about by fecundation may be very similar-parallel results shall in any case be obtained. In the case of brothers and sisters we usually see resemblanee, never cxact likeness of form or character, -oceasionally an unlikeness of form or character. In twins it is a matter of constant observation that the resemblances are usually quite close.

In the latter case, where the conditions of fecundation are alike, and the development of the various germs which make the new being are somewhat cotemporaneous in the time of their development, and consequently exposed to a somewhat similar enviromment, such differences as we observe between the two offspring are to be largely explained by the difference in the forces which were contained in the germs.

The orum, like the sperm, being a representative of a concrete force, which has been made up from the action and reaction of all acts affecting past ancestors which have had any effect on its development, it must follow, as a matter of course, that any individual act affecting the development of these cells, must likewise be represented in the modifications produced in the forees which, throngh the ovum, are transmitted.

On this view we can explain the action of imagination, or of a previous impregnation, upon the offspring. A long continued or a violent impression on the nervous system through the changes following every act through which there is a consumption of force, would necessarily modify, in some form, the development of cells whose functions are peculiarly those of transmissal. The fact that the development of the ovum in woman is checked for a time, during the presence of the child in the womb, and to a certain extent during lactation, indicates the close relition between the germ expelled and in process of development and the cells of the stroma of the ovary. The sympathetic and nutritive relations are undoubtedly quite close, and the forces of the one are being modified through the presence of the other. Such a change may, perhaps, be recognized in the progeny, it depending on our 
ability to more or less readily discern such changes as may have occurred.

Animals, by food, not only maintain the perfect structure of the body, but also lay up in their tissues a store of power for future needs. The power stored for the individual is latent for a time, but reappears and becomes active when required, in the resolution of once living structures, by the vital processes. The force required for the purpose of the germ is derived from the progenitor'; is the germ changes its condition it may derive force through its own development, just as the bocky renews its force through its development. When the force derived from the parent is insufficient for the continuation of the development process to a self-supporting condition, that is, to individual life, the germ must perish. Consider how few germs of the millions contained in the cow's ovary which can ever arrive at a stage when there is a capacity for receiving fecundation.

The primal force-or the force existing at the origin or first recoguition of any of our animals-need not be so inconceivably large. It is not requisite to suppose, with Prof. Huxley, * that in the case of the successive viviparous broods of aphicles, a germ-force capable of organizing a mass of living structure which would amount, as it has been calculated, in the tenth brood to the bulk of five hundred million of stout men, must have been shut up in the single individual, weighing possibly one one-thousandth of a grain, from which the first brood was evolved. The force trinsmitted is but that which has acted on and influenced the transmitting cell, and this cell, under unsuited conditions of development, perishes, and the force is resolved into other forces; or, under suitable conditions, the cell establishes a vitality independent of the parent, with the possession of sufficient force to enable it to add to the forces already possessed, in the way established by natural law. To understand the germ-force of the case of the aphides under consideration, we must conceive of the force transmitted to be at least that sufficient for a single individual, and each individual to elaborate through natural agencies a sufficient power for its own growth and development and for transmissal to its brood in turn. It but transfers a portion of that force

* Organic Reproduction of Aphis. in Tenis. Trans. Vol. XXII., p. 215. 
which itself possesses, and which, through natural processes of development, is segregated from the parent for the purpose of the new individual. The parent, through the vital processes, continually renews and increases the original developmental force through nutrition and other cireumstances of environment. The brood from this parent do likewise, each individual for itself. Deprive this group of aphides of all nutriment whatsoever, and how far could the developmental forces continue?

The germ and the sperm have many points in common, and, as shown by the history of their development, are undoubtedly but differentiated products of the same fundamental clement-the cell. According to the law of persistence of force, the creation of a new product camnot be a forming from nothing, but a transference only of force or forces, form or forms, already existing. The germ and the sperm cannot contain an original germ-force which of itself is sufficient for all futurity, for such a proposition is simply unthinkable. The forces which the germ and the sperm transmit can be what they have, no more nor less.

The germ and the sperm, therefore, contain not the total force and all the forces which are to act during the life of the product, but they do possess the forces necessary to originate the new being and influence the development in certain lines, and the capacity of adding to these inherited forces aceording as opportunity offers. When the forces are insufficient for these purposes the product dies. When the operations of these forces are misclirected by circumstances, - that is, a conflict with other forces, or checked, or accumulated in one direction, or neutralize each other either wholly or in part,changes ensue; and it is this fact, this application of the law of persistence or indestructibility, which explains evolution and insures progress in the development of individuals and races. The forces derived from heredity, and the eflect of nutritive forces on their development, have a dependent influence, not only in the parent, but during the whole life of the germinal product.

\section{GENERATION.}

In some of the lower organisms the egg may be sufficiently organized to continue its development without the added force 
received from the sperm. This is the case with some butterflies, and most notably in the case of the queen-bee, whose eggs, produced under circumstances that forbid the suspicion of fecundation, ean and do advance towards maturity and develop into the completed insect-the drone. In this instance we seem to have the gemmiferous method of reproduction in quite highly-constituted insects, whose continued existence is dependent on the oviparous or true generative process.

In reproduction by division, we seem to have a tendency towards a weakening of the germinal capacity, as is indicated by the consideration of those lower forms of vitality in which the process of nutrition and reproduction are more clearly dependent on each other. Thus, limitations of growth and arising through age indicate a decrease of germinal energy in the reprocluction of cells in the tissues, as also does the converse fact that repair of injuries takes place with far greater completeness and energy in the young than in the old. In organisms that multiply by the fissiparous and gemmiferous methor, there is usually, if not universally, some provision mate for the occasional formation of new beings by the process of fecundation, or of union with distinct cells.

In the plant and in the simple animal life we find a lomogeneity of structure, which has but comparatively fer specialized functions for its cells. Like those parts of the tissues of higher animals which readily undergo repair, these cells are formed mostly through nutritive repetition, and the forces which regulate development appear quite simple in character and evenly distributed throughout the whole cell-structure. Thus the polype may be divided and subdivided, and each portion will develop into a new polype. The twig removed from the plint may form roots and develop itself into an individual plant like the parent stock.

It will be seen that the functions of nutrition and reproduction are, in one sense, allied. They are both dependent for their origination and for the carrying out of their functions upon a force derived external to themselves. In the fissiparous method of reproduction we recognize the process by which both the cells of animal tissues may be formed and the origination of independent individuals among the lower orgunisms. In the gemmiparous method we have an instumee 
in the ova of the queen-bee, and in the preceding section we have shown that the ovum is in essentials an animal cell. The connection between the gemma and the cell may not be so well indicated in some cases as in the hydra, where the gemma thrown off are not merely structurally, but functionally complete; but it is clearly indicated in the zoüspores of an ulva or conferval, where the gemma appears but a cell, yet has the inherent capacity of development into the parent species.

The act of generation is but the union of two cells, the sperm and the germ, whereby a new being is the result. The process in itself is not different in its principles from the other methods of reproduction, but differs in the results following its application. In all cases the only requisite for reproduction is the presence of as sufficiency and variety of foree to originate and support the process we call vital. In simple cells there seems to be this force present, apparently in a ratio with the age of the cell. As we attain complexity of enviromment for certain cells the forces at work, or sufficient for reproduction in the simply-constituted cell, are in part used up in meeting and responding to the changes produced by added complexity, and less is available for the production of new cells like themselves, and reproduction is retarded in proportion as demands are made on the vital forces for other purposes. This antagonism between the nutritive (self-preservation) and the generative (self-propagation) functions has been generally remarked upon by physiologists, and is to be explained by the doctrine of persistence of force.

When the foree inherent is sufficient for preparing the cell for development, and yet cannot compel the development further of itself, on account of the weakening of soime of its fores through expenditure in sustaining the equilibrium between itself and other forces, we may have reproduction by gemmation, the cell east forth meeting with new forces in its career, which its inherent vitality enables it to appropriate for its own use, and through the added force extend its own development. Thus the egg of the queen-bee cannot hatch the drone exeept food he supplied it; and the force within the egg when laid only enables it to develop the grub, a partial transformation towards the completed insect, for the purpose of appropriating and using the forees stored in the food 
and necessary for the completion of the development. The female egg-or that which receives fertilization from the drone-is in possession of an added force, which enables it, in the presence of suitahle food, to acquire unto itself the forces necessary for development into a worker, or eveu into a queen-bee.

In the higher animals we find the process of reproduction by generation universal. In other words, so great is the complexity of their environment, and so complex is their structure for meeting the changes brought about by this very complexity, that we find the various parts and organs of the body highly specialized. As a resultant therefrom, we observe but a limited repair even to the tissues of the body, and this repair far more common in the womb and during childhood than in old age. The generative organs are highly specialized, as they are fitted through long-continued inheritance, with variation arising from the persistence of past and present impressions, for the transmissal of those qualities with which they have or may be impressed. The foree inherent, however, is insufficient, or not of the right quality, of itself, in the male or female cell, to advance further development than the stage in which we find it. By the union of the two forces we have a sufficiency to overcome the difliculties, and a further development may take place.

This statement is illustrated by the experiments of Gairtner, who, after making sucessive trials on at male $a$ with more and more pollen grains, found that a few grains of pollen did not fertilize a single seed; that enough pollen might be added to form a fer seeds of small size, while a sufficiency would produce the full development. Naudin followed the same line of investigation with the mirchilis, in which the pollen grains are large and the ovarium contains but a single ovule. A flower wats fertilized by three grains and succeeded perfectly; twelve flowers by two grains, and seventeen flowers by a single gratin, and of these hut one flower in each lot perfected its seed; and it is worthy of notice that the plints produced by these two seeds never attained their proper dimensions, and bore flowers of remarkably small size.

In the ingenions expreriments of Mr. Newport upon ova of amphibia, it is shown that the contatet of a single spermato- 
zoön is not adecruate to produce complete fecundation; hut that the penetration of a certain number of spermatozoa is reculisite, and that fecundation may be effected partially, so as to occasion some of the developmental changes, by a small amount.

That in development or generation the initial stage is merely the addition of certain forces, is also indicated by the observations of MI. Jourdain, that out of about fifty-eight thousand eggs laid by unimpregnated silk-moths, many passed through their early embryonic stages, thus showing that they had a capacity for a certain amount of development, but only twentynine out of the whole number produced caterpillars. In this case, had the germ-force of the egg been increased by the force added through the process of fecundation, it cannot be doubted but that the caterpillars would have been far more numerous.

Darwin remarks that the belief that it is the function of the spermatozoa to communicate life to the ovule seems a strange one, seeing that the unimpregnated ovtle is already alive, and continues for a considerable time alive, and, as we will add, is capable of a continuous development for a limited extent; limited largely by race and species, but to a certain extont in the individual.

Every consideration that I can bring to hear on my own mind seems to point to the truth that generation is but a form of the accumulation of forces to produce a certain result in exact accorlance with the forces that take part in the process. If the forces become deficient for this purpose, thon development is modified or ceases at just that point where the insufticiency shows itself. If the forces designed to be stored in the two germs, or even in either singly, are diverted from their legitimate purpose of reproduction, then failure, partial or complete, will result, as is illustrated by the seed, which, if secluded from the free access of air and moisture and liept under other suitalble conditions, in order to prevent the expenditure of force, - that is, change, - will preserve its vitality for a long time. Allow, however, the access of air or moisture, or other condition which will induce change in the seerl, the vital force i: expending itself in resisting these changes-that is, forces; and the environment not being suited for growth,- 
that is, the adding as of additional forces,-we have in the seed either a noticealle decay or a complete loss of vitality, or such an insufficiency of vitality that the growth can be but feeble and partial, even if suitalble conditions for its growth and development are now presented it. Among our domestic animals we have additional illustrations in the effects on fecundity following insuffeient feeding, full feeding and, perhaps, over-fecling. Among the Arals a year of scarcity is said to be followed hy one of almost eomplete barrenness among their flocks; and all breeders of sheep are aware of the importance of abundince of food in influencing the production of twins.

Gencration is the actual contact of two peculiar cells and the union of their forces. On the sufficiency or insufficiency of these forces, and on the relative quality of the concrete force presented by the one parent or the other, depends very much the future progeny. The changes following the union of these two generative cells naturally fall under the head of development, for with the conjunction of the two forces the act of generation is accomplished.

\section{DEVELOPMENT.}

In the sperm we have a development taking place in the mother-cell and in the nuclei, but this ceases with the formattion of the spermatozoön. It is the function of this cell to add force, and influence other creations. In the germ, on the contrary, we have a development going on to an almost unlimited legree. The mammalian ovum is, at the time it is fitted for fecundation, fur beyond the simple cell in complexity. It contains various contents, granular in form, and distinct membranes enveloping these and the primary cell and its nucleus, - the vesicle and the germinal spot. The ova of various insects, as remirked with reference to the silli-moth, can develop into intermediate embryonic forms quite generally, while a very small fraction can continue to the extent of the completed caterpillar. The function of the orum is, therefore, to receive forces up to the extent sulficient for its development into the state in which it can maintain of itself its equilibrium with its surroundings.

Parthenogenesis, or the alternation of generation, seems a striking instance of this law of development. The whole 
phenomena may be considered in the light of incomplete development, on account of the deficiency of primal force which it is necessary for the germ to add to, through the process of vitality, before sufficient force can be accumulated for the production of the completed form. Thus the fern sonds forth a spore which is but an incomplete development which obtains and elahorates its own nutriment, until it accumulates sufficient force for the carrying forward of the true generative act, which results in the formation of the new fern.

In so-called arrest of development, it is usually noticed that the defect resembles the same part at an earlier period of embryonie life, so that although growth may have continued, yet it has not developed beyond the grade which it has alreaty attaned in embryo. This is but another illustration of the persistence of force; the inherent power which influenced the continued advancement of the part was deficient, and hence there could be no progress. As the body is but the balancement of all the forces which have taken part in its past history, defects of a character which indicate cessation of force are useful guides towards the study of the past history of the race, or, in other words, the progress of evolution.

It is, perhaps, the place to define what we mean by the term "development." It is the word by which we express the process through which a tissue or orgatn is formed, or by which a tissue or organ or cell is changed so as to be fitted for maintaning its relations with a more complex environment; that is, fitted for a higher function. It is not growth or mere increaso; it is the acquiring not of greater bulk, but of new powers and structures which are adapted to higher conditions of existence. The forees influencing development and growth appear to be of a different intensity and character, yet, under certain circumstances, seem mutually eonvertible each into the other.

Death is the limitation to the power of development. When the demand upon a cell or a life is beyond the power of that cell or life to respond, we find retarded development, or, as it is renerally called, disease, which must end fitally unless the demands ean he lessened or the power of the cell or life increased. When the cells of the hody have exhausted their 
primal force derived through inheritance in the process of development and nutritive repetition, then decay is but a question of time, for without renewal there can be no lasting continuance; for force camnot be created-it can be only appropriated through changes of matter.

The ideal cell repents itself through the force which is stored within it. As forces have been received by the parent cell through nutrition, and as force must have been used by this cell in the support of the processes which accompany vitality, this cell camnot transmit itself, as itself was when first formed, to its own oflspring, but transmits those forces only which itself possesses at the time of the generation or production of the offspring. Each cell, it is thus perceived, possesses within itself the concrete foree received from its progenitors, and the additional or lessened force brought about by the circumstances of its own environment, the sum being the concrete force to be in turn transmitted to its own descendants. As the environment increases in complexity there is a constant demand upon the cell for changes sufficient to enable it to meet this new condition of affuir's. If there is not enough force to the cell to respond, it languishes and perishes. If the force is sufficient to enable the cell to meet the new demands, development follows.

From these remarks will be inferred what the process of development indicates to olmervation, that progress is in the line within which, and in the sequence through which the forces which make up the concrete force was received. Each cell has, therefore, if not interfered with by environment, a primal foree which lules at what suceessive development any change must take place; for if our views are correct, each change must be influenced by the change which has preceded it.

Growth is distinc from development, and does not require such at high vitality, or inpressed foree on the tissues, which compose the substance of the part which is to receive it. A force, therefore, which may be insufficient to continuously develop a portion may be sutticient to preserve form and function unchanged for a time at the extreme limit of the power of the developmental forces, and even to produce increase of bulk, as is so well shown by those calses of alrested 
development where the size remains, but the structural plan is that of a lower grade of animal life, as in malformed , licats where development makes no progress, but the growth goes on to beyond the ordinary bounds.

Let me enunciate a few general laws which may be deduced from what is thus far written.

Each cell contains its proper formative force which determines its future.

The force contained within each cell may be increased or diminished through its environment.

Each cell receives its development to such an extent as is determined hy the forces which it has or may receive,-no more, no less.

Complexity of environment requires in the cell a greater force of resistance and more changes, in order that an equilibrium may be established, than simplieity of enviromment.

The order or sequence of development is the same as that in which the foree which determines the development was received. In other words, persistence of force requires an evolution, a progress onward so long as increased complexity of function is required, and the forces appropriated are sufficient to establish the equilibrium; and the law of inheritance requires that the foree shall act in the order in which they were received, for the sum of the past forces is essential to the formation of the new concrete force.

The general law of matter, that like causes produce like effects when acting on the sime material, also finds expression in this connection. This is illustrated by symmetrical discases. As Paget remarks, the morbid substance in the blood, "fistens, for instance, on certain islands on the surfices of two bones, or of two parts of the skin, and leaves the rest unscathed, and these islands are the exactly corresponding pieces upon opposite sides of the body. The conclusion is unaroidable, that these are the only two pieces that are exactly alike; that there was less affinity between the morbid material and the osseous tissue, or the skin, or the cartilage, (close by, else it also would have been similarly diseased." If we understand by aflinity the expression in a partial form of this law of forces, the matter is rendered more intelligible. The like portions of the body, the symmetrical ones, are developed through like 
forces, and have like powers of resistance to the morbific element.

The more highly organized the structure the longer it seems to take for arriving at full maturity. Thus puberty, brain- cells, etc., illustrate. The process through which maturity arrives is through a sories of constant changes and constant advancement. We all recognize this element of time in the growth and changes of function in the young; it is also conclusively illustrated by the well-estahlished lat of inheritance, through which there is a tendency to inherit at a corresponding age.

There also seems to he an antagonism hetween the processes of growth and derelopment, as has been before remarked on. This is but an expression of the fact that forees utilized in one direction cannot, at the same time, be utilized for another purpose.

If such be the genesis of the progress of cells towards higher capabilities, the same laws must hold true for the completed life-the animal-the harmonious aggregation of these unities and their results.

Going back to the egg, we will trace somewhat of the development, as illustrated by the mammalian ovum. The organized ovum receives additional foree through the conjunction with the spermatozon, and is now enabled to proceed with changes in accordance with its capabilities.

The egg consists of a membranous external sac or envelope, inclosing the spherical yolk, within which is the germinal vesicle and its nucleus. The nucleus, or the germiual spot, is, as we have heretofore said, the spot where is the life, or the power of originating the life. The yolk, however, has a most essential share in the development of the embryo. It may be considered as the contents of a cell of which the germinal vesicle is the mucleus, if we regard this more completed stage of development as a single cell, ats it is clamed to be by Schwann.

The fertilized-that is, strengthened-ovum in a short period commenees to show changes. According to Barry, the immediate eflect of fecundation is to camse the germinal spot to pass to the centre of the vesicle and the vesicle to the centre of the yolk. The spot first indicates a change, which 
is a mark that fecundation has taken place. After a short time the germinal vesicle disappears, and is succeeded by two cells. Each of these twin cells gives origin to two others, making four. Each of these four in turn gives origin to two, by which the number is increased to eight; and this mode of angmentation continues until the germ consists of a mulberrylike object, the cells of which are so numerous as not to admit of being counted. Together with the doubling of the cells in number has been a diminution in size, and ench cell is found filled with the foundations of new cells into which its nucleus has been resolved.

From this germ the embryo begins to be formed. There is a separation into a defined central and peripheral portion, both of which at first appearing granular, subsequently are found to consist of vesicles. This mass hecomes in turn more and more differentiated, and we have an appearanco which has been described as the primitive streak, and a little further in time the dorsal lamine. Thus the development proceeds, constantly showing greater changes and more differentiation of structure.

At first the development indicated is that of the lower animals, as of the fish; then that of the reptile, the bird, the mammal ; then to the species, - variety, - and afterwards to the individual. The progress is from the simple to the complex. It will not be understood that the human embryo is at one time a fish, at another time a reptile, etc. He merely assumes the same type of structure that the bird or reptile assumes in their developmental state.*

It is accordingly seen that a full development of a part into a completed structure is a complex process, in which the forces are changed and are changing constantly, and only after a steady continuance of developmental changes can finslly possess the force of the strength and character fitted for the succeeding structure. The force sufficient to develop the fish or reptile is insufficient to develop the man; and when the force is at that point of accumulation, through inheritance and otherwise, that its strength and direction is in any way equiva-

* For an illustration of this community of structure, as shown by development, see Darwin's "Descent of Man," Vol. I., p. 15, where drawings of a human embryo and of an embryo dog, at about the same stage of derelopment, are contrasted. 
lent to somewhat the same force used in the derelopment of another animal, there must needs be shown a resemblance. Persistence of force, therefore, shows a necessity for the beliof in the gradual evolution of one type from another, in all cases where conditions of life are becoming more complex.

At the birth of the young being development does not coase. The parts are continually gaining in power, and are changing in form throughout the period of youth. As the infant increases in age he develops more capabilities, either through the perfection of old or the formation of additional structure. As the forces decrease in intensity the child-now become $a$ man-is said to be growing old; and when the forces give out, then development ceases; there is no capacity for the gathering in of the power that is necessary to supply the force consumed in the labor of living, and death ensues. Partial failure to meet this equilibrium may produce disease only, and the patient, by gradually regaining this equilibrium betreen expenditure and supply, may recover his health.

Life and death, development, reproduction, generation,all are the expression of the effects under general laws, of which that of persistence of force is the chief. Inheritance is shown in development, as in ovulation and generation. It is but the expression of facts of our observation; and it is by the study of development that we are able to assert that heredity is an expression of the action of general law-persistence of force as applied to vitality; - a law so powerful and universal in its conception, that once given vitality and constant change of environment, and if vitality entures, development must of necessity ensue. In each, cause must produce an effect, and we thus have change. In the change we camnot conceive of no effect following the altered circumstance, so that neither the cells nor their concretion, the body, after once having undergone a change, can transmit the same qualities or forces that they could have done if unchunged. By the same law, transmissal or development of forces can only take place in accordance with the order in which they were received, for force modifies force; and no concrete force could be just what it is had there been any change in any of the individual forces, whose totality is the result before us. 


\section{GROWTH.}

There seems a difference between the force utilized in growth and that utilized in development. It is of a more simple power, on account of more simple requirements. Development appears to be dependent more on the primal or inheritalble foree than growth, which is derived principally from the forces acyuired during life, as from food, otc. The two methods are, however, in large degree interchangealle. The essiential element of growth is the reception and adding on of new material, whereby bulk is oltained, or a nutritive repetition. Growth and development are usually coincident.

As an illustration of growth without a corresponding development, wo have the malformed heart. Among the collections in the museum of the Royal College of Surgeons, writes Paget, one anong them presents only a single cavity; no partition has been cleveloped between its auricles or its ventricles; it is, in respect to its development, like the heart of a futus in the serond month; but though its development was checked thus early, its growth continued, and it has more than the average size of the hearts of children of the same age.

In the cell, growth may be manifested in the increaso in surface or thickness of the cell membrane, or the cell departs from its primitive globular character in such a manner that the cell membianes only add new substance and extend out two or more points. The membranes may become thickened or changed through an infiltration or deposit of hard substances, which may add bulk, or the cell may also divide and form new cells, and these in turn others, while the part necessarily increases in size through this increase of cells. In this case we may have growth to the part and development to the cells. We see instances of this process in the whole history of fuetal and early life. In adult age we may have increase of a part through exercise, which result is usually an indication of health. We may have, moreorer, growth and development coexistent in the adult in some cases, which are pathological, as in those cases of hypertrophy in which the enlargement of a part is effected with increase of its natural tissues, with proportional retention of its natural form, and with increase of power. 
This increase through excessive cell action is, of course, from this doctrine of persistence of force, more or less inheritable. We are not surprised, therefore, to find instances of transmission of obesity in families, or of strength, or of peculiar traits, involving an excess of activity of cell action, as mental inheritances, inheritances of milking qualities in the cow, etc. When the action of growth is accompanied by the action of development, it seems probalble that the force is of a more perfect character than is the force requisite for growth alone. That is, a force sufficient for growth may not he sufficient or of the right quality for influencing and carrying forward an extended development. When a force is insufticient, we should expect either a partial or complete failure, and also that the exact form in which the failure should come about would vary according to the circumstances affecting it. We can thus theorize on those cases where parents of the ordinary size have given birth to dwarfs and to children of ordinary size. A force insufficient for development should bring ahout an alyortion, or a failure in the offspring accuniring that degree of existence in which the vital powers are alble to add the forces requisite for completing the process for arriving at maturity. A force insufficient for a vigorous growth might, under peculiar circumstances, allow the derelopmental forces to continue in the formation of the young. Durdach cites an instance of one man who had eight children from the same wife, of whom four were dwarfs ; and Prosper Lucas another, where of six children two were dwarfs.

Developmental and growth foree, however allied, and howerer much they may influence each other, yet appear to hare this essential difference: growth is the absorption or gaining of power through a direct increase or gain arising through the presence of additional foree, which is appropriated under the influence of the developmental force. A process in its conception simple, developmental force is a concrete force, brought about through complexity of environment, and its existence depending largely and primarily on forces accumulated in the past. As a summary, growth and developmental forces are alike enntrolled by their past history, viewing the forces controlling each at any particular moment as a concrete force; but the forces which regulate growth are increased more 
readily by a certain form of enviromment, nutrition, than are the developmental forces. Development is a higher form of foree, and is at a further remove from the inorganic than growth. To repeat, the process of growth is fur more under the sway of nutrition than is that of development. The ill-nourished plant may develop during growth, but the growth is stunted. The rag-weed of our gardens can be cut to the ground, and be exposed to great extremes of drought on a gravel knoll, yet if there is vitality left, it will bloom and ripen its seed, with an extremely scanty growth. This plant, in a rich and congenial soil, may be three feet tall; under adverse circumstances the same process of development, in kind, may take place in a plant under two inches tall.

We have, in growth, an unknown though probably determinate limit. $U_{p}$ to that limit growth can be accelerated, and even forced, hy nutrition. Within limits growth can be retarded; even a diminishing of bulk can take place through the withholding of nutrition. Growth influences development; but no amount of growth,-or, in other words, the presence of unlimited nutrition,-apparently, aflects development but in very cireumseribed limits. The conception of growth is simple,-accretion, as a crystal, may be said to grow from the deposit of its own material from the surrounding menstruum. The conception of development is complex, involving an adjustment of many forees, operating through long periods, and includes growth.

Growth is distinct from development, yet allied; is determined under the directions of the same laws which govern development; yet the forces which determine growth and development are different, in the same respect as are diflerent the forees which determine different exhibits of development. All vital processes are the footing up of an unknown column of figures that go back to the begimning. Every unit tells, and some are plus and others minus. The phenomena we observe is their atdition, and the integer is fixed, although perhaps not determinate to us. These integers are different in every case. Higher in development than in growth, and the tendency to increase aceording to the number of units furnished through an increased complexity of enviromment.

Growth is in sequence before development, as it is depend- 
ent on simple causes; for the law of all nature is from the simple to the complex, rather than from the complex to the simple.

\section{SUMMARY.}

The laws of breeding may be likened in their development to a tree. First the root, then the trunk, branches, twigs and leaves. The root represents law, - the law of causation,or, as it may perhaps be called, the law of unity,--the law which directly preserves the harmony of all nature. This primal law is the idea, which, as a conception and as a fuct, is the support of all processes of thought, whether of induction or deduction. The trunk stands for the conception expressed by the term persistence of force (a law scarcely of less universality than that of causation), liecause on it are built up all the rest of the parts united with and flowing from it. The limbs repreneut in turn subordinate and connected laws, - such as those of resemblance and variation. The twigs, other laws still more subordinate to the rest,-such as find expression in the terms reversion, prepotency, etc. The leaves can bring to mind the laws directly affecting the species and the individual.

We might use in illustration a figure calling attention to the gradual succession and inter-dependent position of laws, whose understanding constitutes the science of breeding, the whole structure passing from the periphery of individual facts through successive gradations of deductions, in which the facts reappear in successive integers, until all observations unite into a completed aggregate, and give conception of and expression to the law founded in nature arailable for this development or evolution.

In our several divisions we have traced the law of persistence of force, as well as regarded the law of unity, by consilfering in turn those parts and functions which take part in the formation and evolution of the adult life. We have shown that the germ and the sperm-cells have a development analogieally parallel, and that they are governed in their derelopment hy the operation of the same laws. We have attempted to show that, in generation, we have but an expression of the same laws which operated to procure the elements essential to it. That development and growth, the sequelie to generit- 
tion, are governed by precisely the same laws, bearing in mind throughout the eflect of complexity produced by environment, and the influences predicated on the general laws involved. Wre have thus hoped to have established the connection of the law of persistence of force with vital operitions, and its importance as offering an explanation for all the facts involved in the consideration of evolution.

Biological science is under the control of those great laws. which regulate the cosmos, and tho law of the persistence of force is the chain which, permeating life in all its hranches, links its phenomena with those of the universe. Evolution is not the causo of changes of animal forms and instincts; it is not merely an expression of the observed facts of animal advancement; it is an expression of the process of development under the law of persistence of foree. When this beattiful law is once apprehended, there can be no escape from the deductions which are seen to flow directly from it.

In studying the phenomena attending the breeding of domestic animals, we have in this law the key for the investigation of tho observed changes, and the science of brecling is established. With study and observation all practical details which are precisely apprehended can be seen to be so connected with previous and existing phenomena, through the expression of this lnw of persistence, as to constitute a science ; for science is nothing more than the tracing the lines accurately between effects and their preceding causes.

\section{APPLICATIONS.}

There are many operations of nature, otherwise inscrutable in their relations, which appear to be explained through this law of persistence of force. Under the consideration of eflects through law, phenomena hecome linked with phenomena, olservations become mole exact, and the horizon of our investigation becomes cleared. Let us see how far the theory we have herein dereloped will serve us in the consideration of those changes, which may he gromped in detail moler the title of subordinate laws of inheritance.

We will just call attention to what we have claimed in our context, that heredity is itself developed in strict conformity to the principles developed by this law. For the new foree, 
concrete in the offspring, is but at first a transference of forces possessed by the parent. To illustrate more fully: the piece elipped from a polype is but a portion of the polype formed hy the same forees, and its development impressed by the same force which caused the development of the body from which it was derived. Therefore, in the absence of counteracting influences, there must he resemb'ance between the two pieces, the parent and the new individual,_-the offshoot. The law of variation is also a development moler this law; for causation, being universal, and the environment under constant change, it is inconceival,le that two inclividuals should be exact counterparts of each other, no matter how neal their kinship. Thus constant changes produce corresponding variations, and, so long as vitality exists, there is at constant effort on the part of living structure to maintain itself in equilibrium with the varions forces affecting it, and we hence have the possibility of evolution. In the phrase, heredity with variation, we have an expression for conditions which are unmistakably directed and ruled by law.

On a general law of vital periodicity.-Herbert Spencer, in his "First Principles," devotes a chapter" to the Rythm of Motion, in which he derelops the fact that all changes appear to possess a periodicity of character, and that wherever there is a conflict of forees not in equilibrium, a rythm results; yet as motion is never absolutely rectilinear, rythm is necessurily incomplete. Wre find this same law cxemplified in animals,tho vital functions all tending to run their course in fixed and recurrent periods, as illustrated lyy gestation and the phenomena accompanying it, certain processes of development, ete. In like manner, as the geysers of Iceland are intermittent,their spoutings ceasing, until, in process of time, sullicient forces are accumulated to overcome the resistance of the colmm of water which is expelled hy the explosion,-so are certain vital actions which require the expenditure of much porver, and even as is a priori probable, all actions whatsoever have a period of apparent quietude while they are aceumulating the forees necessary for overcoming the antagonistic forces which they nect; for conflicts are continually occurring in nature, and a struggle exists, real, although often umoticed, to maintain that constant oquilibrium which is the oljective 
point of vitality. These rythmic actions, once formed, tend to he transmitted under the law of persistence of force, and the conditions involved fall under the laws grouped subordinate to inheritance. Hence a general periodicity, exhibiting itself as a law, and race, species, individual periodicity everywhere, alike in principle, differing in detail.

Churacters common to many species of a genus are found to resist rariation, or to reappear, if lost, more persistently than the churacters which are confined to the separate species; * and the longer any character has been transmitted by a breed, the more firmly it will continue to be transmitted. $\dagger$ These two propositions are essentially similar, as dependent for their establishment on similar facts of olservation. In general terms, antiquity of character adds strength. From the consideration of the laws involved, we see that each cause must produce a corresponding effect, and as each germ is a concrete force representing the sum of all the forces, whether plus or minus, acting on its past, it must be influenced during each generation by the continued presence of the same concrete foree. The truth of this reasoning is illustrated by the facts of erolution, that generic characters are stronger than specific charracter's; that individual variability is general, and specifie resemblance more constant; that crossing tends to produce variability, and breeding to pedigree to produce likeness. The apparent exceptions to this law of antiquity of character are numerous; for whenever, from whatever cause, another force prevails for a season, this prepotency gained from antiguity in natural conrse may disippear ; but the fact that this disippearance is oftener in individuals than in species, and in species thain genera, illustrates the correctness of our law. Now, the accumulation of forces in one direction, either through a "spontaneous" (?) variation or through breeding, may, and often lises, introduce a prepotency which will prevail over chanacters which have been assumed during many generations. This is illustrated by the Shorthorn cattle, a companatively modem hreed, which seems prepotent over the majority of the breeds with which they are crossed. The Aneon sheep, as well ats the Manchample merinos, are illustrat-

* Darwin, An. and Pl., under Domest., Vol. I., p. 139.

$\uparrow$ Darwin doubts, ip. cit., Vol. II., 1. 82. 
tions of "accidental" (?) variations, being prepotent over long-assumed characters; but in these cases the results were partially aided by selection.

Embryo more slightly modified than adult animal.-In the womb there is a striking resemblance between the products of very diverse animals at certain periods of their growth; and it is as growth advances that the differences become definite enough for immediate recognition. In the young animal, as in the foal or calf, the difference between animals of different breeds is at birth but slight compared to those which exist between the adult animals. In certain characters, such as the sexual, we find development only occurring at a considerable interval from birth. This one instance of a process continually in action may be formulated in the law of development at corresponding periods of life. It is clear that these two expressions of facts, in constant occurrence, are somehow linked together, - - the young animal being but a continuation of the embryonic life under changed environment. When we consider that each animal is, in turn, the sum of his past, plus his present,-that is, the force which has originated, or which we recognize as vitality, has changes impressed on it during each period of its history, it will be perceived that the existing animal could not be exactly what it is if any change had taken place in its previous condition. Under the law of persistence of force, each concrete force is just what it is through the changes which have been impressed on its constituent units or parts. Any change of its unities, at any one period of existence, produces a corresponding change in the nature of the concrete force, whose expression is the specific or individual life. We therefore have periods of development; for, in the reproduction of an animal, the forces come at first entirely from the past, and are modified in turn by their entire past; and these inherited forces afterwards act against, as well as are modified by, environment. But to have a concrete force resembling another concrete force, there must be a similarity between the causes which have produced or developed. At each moment of the history of an animal, changes are being impressed, and the state of the animal at this moment has been determined by its previous 
state. We thus have a continual series of changes going on under law, in which the past forces are continually in action, and a given result can only occur through predetermined forces in the past. Hence an order to development. Hence the element of time, during which changes 4nay occur in succession preparatory to the final result. Hence, in embryology and immature growth, a guide for the study of the history of past changes or evolution.

Correlated variations, as of homologous parts, and correlations in general, can be understood under this view of forces, continuously modifying and influencing each other. When the phenomena of life first appeared, the struggle for existence commenced, and in meeting the requisite equilibrium, changes became impressed in relation with the complexity of environmental forees, differentiations occurred, and the animal was gradually built up in its wondrous intricacy, yet harmony ; each force concerned acting on, and being acted upon, by other forces concerned. Where we recognize this action of one force (considered concrete in its results) upon another (considered likewise), we define the action as correlation. Thus, in all the breeds of the pigeon, the length of the beak and the size of the feet are correlated. All modifications which occur influence subsequent developments, not only of the same parts, but also of all other parts with which it is intimately enough connected. In this we have correlated variations, in this but an expression of results following the doctrine of the indestructibility of force, which tenches that foree, in common with matter, cannot be created, but can only be converted, and is subject to changes, but never to loss. In the correlations between hone and hair, we have different structures built up in part from the action of the same forces, as is shown by the history of their development. We therefore have a certain affinity between them, and a change impressed on one is apt to be followed by corresponding changes in the other. Were we sufficiently acruainted with the forces which go towards making up the animal, the numerous immediate fores could be referred to successive intermediate forces, into which they could be grouped, until finally the simple force would be reached,-a conception 
expressed by vitality in the abstract. Correlation is, consequently, but another expression of persistence of force. It is a recognition of the mutual dependence of all structures upon simple, harmonious law.

Prepolency.—As all causes are followed by effects, we must believe that forces which have long acted, or have been accumulated in one direction, have done so to the exclusion of other forces which might have acted in their place, and hence must be supposed to have had a stronger influence than if they had acted through a less period of time, for continued oflects must have followed their continued presence in an unstable equilibrium, like vitality. Hence, the term prepotency expresses the fact that a force, through long continuance or otherwise, has, through, its own strength, acquired a preponderating infiuence over other forces. We thus have prepotency of breed, - as illustrated by the case given by Godine, where a ram of a goat-like breed, from the Cape of Good Hope, produced offspring hardly distinguishable from himself when crossed with ewes of twelve other breeds; prepotency of sex, - as illustrated by the Shorthorn bull "Favorite," referred to so often in Shorthorn pedigrees. Trhen, from any cause whatsoever, a force acts in a manner stronger than another force, it is prepotent. If forces have been accumulated through selection, or through breeding in any one direction, we have a prepotency of such forces over other forces which are mable to resist, - each force stauding on its own strength, however it may have heen accumulated. Pedigree, or the breeding in line, has a tendency to strengthen the points of value; so also has purity of race; so also has selection; so also has the accumulative action of changed conditions of life. Prepotency is, therefore, but a term expressive of a fact, that of a number of forces found amid many diverse conditions, - -as in the maintenance of an equilibrimm with changing conditions,-some are stronger than others. If we consider force as persistent, and bear in mind the law of causation, the predominance of some forces over others becomes a necessity; and the continuation of a force through a long time, that is, antiquity; or the accumulation of forces in one direction, as by breecling to pedigree; or any 
other method through which we obtain causes acting continuously in one direction, strengthens such forces, and produces in those cases where the action is recognized, the phenomena called prepotency.

On the relations between the period of development of a character and its transference to one sex or to both sexes; or, as again more fully expressed by Darwin, variations which first appear in either sex at a late period of life tend to be developed in the same sex alone; while variations which first appear early in life in either sex tend to be developed in both sexes. As sexual characters receive their development late in life, through the doctrine we are here enunciating there must be, necessarily, a correlation between the sexual distinctions and those parts developed under process of law at the period of their activity. Inence, a prepotency through sex might be established. In early life, the sexual organs being immature, there is less of correlation with sex, and, consequently, less sexual prepotency. When, therefore, the adult male differs from the adult female, and from the young of both sexes, we may assume that the variations which brought it about occurred late in life; for, through the transmissal of forces, the adult is the product of forces acting through the young, and the history of the development must furnish a clue to the order in which the changes have occurred. When the adult male closely resembles the adult female and the young of both sexes, the variations through which their characters were acquired occurred in early life.*

Inheritance limited by sex.-In correlation of structure, brought about through persistence of force, we seek an explanation for this curious phenomenon. It is seldom that this species of inheritance is absolute; but this can be explained from the fact that, in foetal life, the distinctions between the sexes are less than in adult life, and therefore their iufluence is less strongly markel upon correlations. It must be borne in mind that the individual is the product and the equilibrium of all the forees which have had to do in his making, both past and present. Originally, a simple force, becoming differentiated, changes character, and concrete

* Darwin, "Descent of Man," Vol. I., p. 277. 
forms result, the direct effect of the changes which are aflecting and have acted. The sexual changes are of importance; produced by environmental circumstances, they in turn, as concrete forces, must influence the whole structure. This they do, beyond denial, and sexual distinctions must especially influence, to some extent in early life, to a great extent in adult life.

Inbreeding-Crossin\%-Close inbreeding has a tendency to induce sterility, while crossing is universally regarded by breeders as bringing vigor. Darwin regards it as an established law of nature, that all organic heings profit from an occasional cross with individuals not closely related to them in blood; and that, on the other hand, long-continued close interbreeding is injurious. It is the belief of physiologists that every act of development tends to diminish the germinal capacity, while every act of generation tends to renew it ; and it is even probahle that in plants even self-fertilization seldom occurs, but the stigma receives pollen from other flowers than its own through contrivances often of the most wonderful complexity. This is a form of expression for the fact that every change is brought about through the utilization of a force, and that the forces may gradually bocome weakened in producing changes unless a power of regeneration be given them by a union with fresh forces. In inbreeding we are dealing with forces of a similar character,-that is, they approximate to a nearer likeness than do the forces the product of an out-cross, on account of having a greater similarity of history in their past. We consequently have an approach towards the development of new individuals without the intervening act of generation,-as, by fission, gemmation, etc.; that is, an approach towards a developmental process, as distinguished from the generative process, and, consequently, a tendency to shorter duration to the life,- - this means weakness, lessened constitution, etc., etc. In an outcross, on the other hand, we have an entire departure from the developmental idea towards the generative, and a consequent vigor, or renewal of force. If the out-cross he, however, ton violent, a hybrid may be the result,- that is, the forces necessary for fertility are absent, either on account of too great 
antagonism between the forces present in either parent, or hecaluse they are not of such a nature as to combine. In hylnids, therefore, we have usually sterility, but also the possibility of producing oflspring, —as, indeed, is occasionally the case,-the result depending upon the structure and composition of the forces which severally are engaged. In mongrels we find great variability and little prepotency, as a rule, all resulting from the doctrine of persistence of force.

The other effects of inbreeding-as the transmission of defects in an accumulated form-fall directly uncler the fact of inheritance, and need not be considered in this place.

The unequal fertility between reciprocal crosses connects the consideration of mongrels and hybrids, and seeks explanation from the same laws.

In crossing animals of the same race we have a union of forces under the laws of breeding, but on account of our little knowledere concerning the relative strength and the combined action of the forces we are using, the results are apt to be very varialle. When two forces meet in antigonism, each is morlified and changed according to the law of mechanies, but neither fore is olliterated; the effect of the struggle remains, while the forces may be in abeyance. Like the circular ripple of the pebble dropped in the water of smooth surface, the effect is ever acting, ever extending, and we thus have a series of actions modifying changes for all time. Characters in an animal are never obliterated, but may disappear from our view. We have, in crossing, a means for the modification of race, hy producing changes through direct antagonism of force. We also have in free crossing a merns for the preservation of uniformity hetween members of the same race. Like a two-elged sword, the law of erossing cuts both ways, according as its principles are applied, and under the govermment constantly of the great law of nature, - that of the persistence of foree. As the antagonism of forces may be eonsidered in the light of a mutunl abserption, other forces, too weak to otherwise appear in a form recognizable to us, may appear. Hence, we say, that crossing produces a tendency to reversion or atavism.

Selection.-This is simply an expression of a means to an 
end. It signifies the accumulation of a force in a chosen direction. As used by the breeder, selection means modifying the laws of animal nature through human knowledge and skill, so as to predetermine the result. If unconscious, it is the accumulation of prepotency through law, not under the voluntary direction of man. The very terms used in discussing the doctrine of selection, presuppose the doctrine that force is persistent and is subject to the law of matter.

Malfurmutions. - These are all subject to law, which is not only a priori reasonahle, but which has been already partially formulated and discussed. These, whether monstrosities or the opposite, can derive an explanation from the consideration of the doctrine of forces. In the case of dwarfs, developmental force is present, growth force seems defective. In monsters, we may have a deficiency of certain forces at a determined point, as in cases of arrest of development, or an accumulation of forces in a direction injurions to the individual. Nature only attains perfection (equilibrium) through repeated efforts, and those not fitted to exist perish in the struggle of life.

Inagination. - That there is an influence between the wombcontents and the mother, is illustrated in many ways. In the woman, the development of new ova is checked upon the occurrence of impregnation, and lactation also appenrs, in the majority of cascs, to Lave the same effect. Disenses of these parts are apt to produce mental disturbance, and in other ways a close comnection is shown between the mental and reproductive functions. Causes, therefore, acting on one must necessarily affect the other; and, through persistence of force, the child must also be influenced in turn, for it receives its supply of force through the mother. The physical connection of mother and ollspring is nut, howerer, direct, and the influence of one on the other is not as well marked as if it were otherwise; yet the influence on ench other must be reciprocal. An impression of long duration would seem to have a power greater than one of short duration, or even, possibly, than a violent impression of short continuance.

Effects of a previous impregnation.-By the law of causation, there must be a mutual relation between mother and 
offspring in the womb. We recognize this fact in practice, and in reasoning it naturally follows from persistence of force. The force received from or through the father, uniting with the force presented by the female, coalesces, and during growth and development must influence, in some way, the female structure,-for causes and effects are correlative; and we have in the young, modifications, through developments and growths, going.on continuously, supported from the mother; and it is unthinkable that there is not an effect being produced, in turn, on the mother from these operations. 


LIBRARY OF CONGRESS

00028181152 